\title{
Motif Sosiogenesis Pasangan Roleplay Dalam Media Sosial Twitter
}

\author{
Laras Puspa Pratiwi, Assas Putra \\ Program Studi Ilmu komunikasi, Fakultas Komunikasi dan Bisnis Universitas Telkom
}

\begin{abstract}
ABSTRAK
Dalam media sosial twitter terdapat sebuah fenomena baru dikalangan penggemar Korea, yaitu roleplay dimana seseorang memerankan tokoh idola yang mereka sukai. Dalam dunia roleplay sendiri terdapat istilah pasangan roleplay dimana roleplayer berpasangan dengan roleplayer lainnya yang menyebabkan munculnya realitas baru di dunia maya yang salah satunya adalah adanya pernikahan virtual antara pasangan roleplay tersebut. Penelitian ini berjudul Motif Sosiogenesis Pasangan Roleplay di Media Sosial Twitter. Tujuan dari penelitian ini adalah untuk mengetahui motif sosiogenesis (motif sekunder) dan interaksi yang dilakukan oleh pasangan roleplay di media sosial twitter seperti media yang digunakan dan pengaruh intensiatas interaksi ke dalam hubungannya dan juga kedalam dirinya sendiri. Paradigma dalam penelitian ini menggunakan paradigma konstruktivis dan metode yang digunakan pada penelitian ini adalah metode kualitatif dengan menggunakan studi etnografi virtual. Serta teknik pengumpulan data yang dilakukan meliputi wawancara mendalam, observasi, dokumentasi dan teknik keabsahan data dalam penelitian ini menggunakan triangulasi teknik. Informan dalam penelitian ini terdiri dari empat orang. Hasil dari penelitian menunjukkan bahwa ada tiga motif yang mendasari terjadinya pasangan roleplay dalam media sosial twitter, yaitu motif ingin tahu, motif cinta, dan motif harga diri. Dalam berinteraksi, media yang digunakan oleh pasangan roleplay adalah kakaotalk dan Line messenger. Selain itu, intensitas interaksi yang dilakukan oleh pasangan roleplay dapat mempengaruhi kedalam hubungan mereka juga kedalam diri mereka sendiri.
\end{abstract}

Kata kunci : Couple Roleplay, Etnografi Virtual, Interaksi, Motif, Roleplay,

\section{Sociogenic Motive of Couple Roleplay in Social Media Twitter}

\begin{abstract}
In the use of social media twitter, there is a new phenomenon between Korean fans, which is roleplay, where someone acts is a the idol they like. In the roleplay world, there is a term 'couple roleplay' for a situation where a rolepalyer paired up with another roleplayer and creates a new virtual reality, one of which is a virtual marriage of the couple. This research is titled 'Sosiogenic Motive of Couple Roleplay in Social Media Twitter'. The objection of this research is to kow the sosiogenic motive (secondary motive) and interaction of the couple roleplayers in twitter such as the media used and the influence of intentional interactions into their relationships as well as within themsleves. the paradigm in this research uses constructivist paradigm and the method used in this research is qualitative method using virtual ethnography study. The data collection techniques used in this research are deep interview, observation, documentation and technique of data validity in this research using technique triangulation. There are four sources for this research. The research shows that there are three motives for couples in roleplay in twitter, which are curiosity motive, love motive, and self-esteem motive. In interacting with each other, the media used by the couple
\end{abstract}


are KakaoTalk and Line Messenger. Futhermore, the intensity of the interaction between the couple can affect their relationship as well as their own self.

Keywords: Couple Roleplay, Virtual ethnography, Interaction, Motive, Roleplay

Korespondensi: Laras Puspa Pratiwi. Universitas Telkom. Jl. Telekomunikasi, Jl. Terusan Buah Batu No.01, Sukapura, Dayeuhkolot, Bandung, Jawa Barat 40257 Email: laraspsp@ gmail.com

\section{PENDAHULUAN}

Pada era internet seperti saat ini, manusia sudah tidak asing lagi dengan media sosial. Media sosial adalah perkembangan baru internet yang saat ini sedang booming. Hadirnya media sosial saat ini sudah bisa dianggap dapat membantu. Media sosial adalah platform di internet yang memungkinkan pengguna saling bekerja sama, berbagi, berinteraksi, berkomunikasi, dan membentuk sebuah jaringan komunitas secara terbuka (Nasrullah, 2015:11).

Kehadiran media sosial sendiri telah menjadi fenomenal. Facebook, Twitter, Youtube, hingga Path adalah beberapa jenis dari media sosial yang diminati oleh banyak khalayak. Media sosial tersebut tidak hanya digunakan untuk mendistribusikan informasi yang bisa dikreasikan oleh pemilik akun (users) itu sendiri, tetapi juga memiliki dasar sebagai portal untuk membuat jaringan pertemanan secara virtual dan medium untuk berbagi data, seperti audio atau video (Nasrullah, 2015:3).

Twitter menjadi tempat atau sarana yang digemari untuk mengekspresikan diri seseorang, berinteraksi dengan seseorang, menyampaikan suatu ide, tempat bagi seseorang untuk berjualan, mencari hiburan, dan mencari infromasi. Berdasarkan kategori besar Media Sosial, twitter termasuk dalam jenis kategori Micro-Blogging yang memungkinakan pengguna untuk mempublikasikan aktivitas dan pendapatnya dengan menulisnya sebanyak 140 karakter atau iasa disebut dengan tweet. Tweet sendiri bisa terdiri dari pesan teks, foto dan video.

Situs twitter ini memiliki banyak manfaat seperti mendapatkan teman baru, berinteraksi dengan orang jauh, berjualan secara online, memberikan serta mendapatkan informasi dan juga sebagai wadah bagi suatu komunitas. Berbagai Penelitian tentang twitter selalu terkait dengan konteks pengguna yang berbeda-beda. Maksudnya adalah, habit, kebiasaan, pengguna twitter di Negara A belum tentu sama dengan pengguna twitter di neagara B, dst. Indonesia sendiri adalah salah satu Negara yang lansekap pengguna media sosialnya mengalami peningkatan pesat dalam beberapa tahun belakangan ini. Indonesia juga memiliki basis pengguna twitter yang sangat besar. (Semiocast, 2012;Lim, 2012 dalam Mahameruaji, 2016). Sehingga dapat diakatakan bahsa penelitian tentang twitter dengan berbagai topik dan metode penelitian 
masih sangat relevan untuk dilakukan di Indonesia

Salah satu contoh interaksi yang dilakukan pengguna twitter yaitu dengan membuat suatu komunitas cyber dengan mengumpulkan orang-orang yang memiliki suatu kesamaan baik minat akan sesuatu hal ataupun visi dan misi dan menciptakan suatu budaya tersebdiri dalam dunia cyber atau lebih dikenal dengan cyberculture. Cyberculture secara sederhana melihat bagaimana budaya itu berada di cyberspace, sebagaimana bahwa internet merupakan ruang dimana budaya yang terjadi itu diproduksi, didistribusikan, dan dikonsumsi (Nasrullah, 2015:74). Pada dasarnya cyberculture dapat diuraikan atas budaya dan cyber. Budaya merupakan nilai-nilai yang muncul dari proses interaksi antarindividu. Merujuk arti budaya dalam Kamus Besar Bahasa Indonesia, "budaya" bisa diartikan sebagai (1) pikiran, akal budi; (2) adat istiadat; (3) sesuatu mengenai kebudayaan yang sudah berkembang (beradab, maju); dan (4) sesuatu yang sudah menjadi kebiasaan yang sudah sukar diubah.

Secara sederhana, kata "cyber" merujuk apa yang ada di internet. Namun, tidak hanya internet sebagai sebuah perangkat teknologi yang termasuk ke dalam konteks cyber tersebut, tetapi juga interaksi, komunikasi, data, perangkat antarmuka, sampai pada penggunanya. Ada tiga kunci dalam memandang internet, yakni material, simbolik, dan pengalaman (Bell, 2001 dalam Nasrullah, 2015:77). Pendekatan material melihat internet sebagai sebuah perangkat teknologi yang harus dilihat dari aspek sejarah, mulai dari era APRAnet hingga saat ini.

Dalam konsep simbolik, internet merupakan simbol yang tidak bisa didekati secara virtual, abstrak, dan tidak nyata saja. Tetapi juga dapat dimaknai sebagai ruang dimana produksi, sirkulasi, dan konsumsi penggunanya ternyata memberikan efek terhadap bagaimana invidu itu sendiri memiliki pengalaman dan membangun impian di cyberspace. Dan yang yang terakhir dalam konsep pengalaman, cyberspace memberikan arah atau pola bagaimana interaksi yang terjadi antara individu dengan perangkat teknologi maupun antarindividu melalui perangkat tersebut.

Maka, dalam bukunya Nasrullah (2015:84) menarik kesimpulan bahwa cyberculture adalah praktik sosial maupun nilai-nilai dari komunikasi dan interaksi antarpengguna yang muncul di cyberspace dari hubungan antara manusia dan teknologi maupun antarmanusia dengan perantara teknologi. Budaya itu diproduksi, didistribusikan, dan dikonsumsi melalui jaringan internet dan jaringan yang terbentuk di antara pengguna. Konsep cyberculture ini kemudian harus dipertegas kembali dengan melihat bagaimana internet sebagai budaya 
dan artefak kebudayaan (Hine, 2001 dalam Nasrullah, 2015).

Dengan adanya duinia Roleplayer di dunia virtual ini juga secara tidak langsung telah membentuk sebuah cyberculture. Kebudayaan baru yang mereka bentuk di cyberspace ini lah yang disebut dengan artefak. Komunitas cyber dilakukan selain untuk kepentingan dan tujuannya masingmasing salah satunya yaitu untuk mengisi waktu luang dan sebagai sarana hiburan semata. Mengapa bias terjadi demikian, Wahyudin, Ronauli, Elita, Mirawati (2016:125) menyatakan bahwa pesan-pesan melalui media sosial berpengaruh terhadap sikap dan gaya hidup masyarakat

Bahasa begitu sering menjadi satusatunya bentuk komunikasi di CMC, maka bahasa ini menjadi sarana utama untuk mengelola dan membentuk kesan diri sendiri dan orang lain. Seseorang bisa menjadi beberapa orang lain secara bersamaan, sebagian besar seseorang menggunakan internet sebagai cara untuk bergulat dengan masalah psikologis seperti hubungan dengan orang tua atau dengan pasangan dan berpendapat bahwa MUD (Multi User Dungeon) adalah 'ruang istimewa untuk berpikir dan bekerja melaui isu-isu identitas pribadi' (Nancy, 2006)

Banyak pria yang berpura-pura menjadi wanita dan menggambarkan dirinya menarik secara seksual dengan cara yang sangat stereotip. Begitu juga para remaja wanita yang salah menggambarkan penampilan mereka secara online. (Clark dalam Nancy, 2006). Dalam CMC, anonimitas digunakan dengan berbagai cara dalam konteks yang berbeda. Dalam beberapa kasus juga menawarkan kesempatan untuk mengeksplorasi identitas yang belum dicoba atau hanya untuk memalsukan diri. Dalam kasus lain, seseorang menawarkan kebebasan untuk bersikap lebih terbuka dan jujur daripada yang seharusnya dilakukan.

Sama halnya dengan sebuah komunitas cyber yang juga sebagai sarana hiburan dalam media, muncul istilah baru dalam dunia twitter yang menjadi salah satu komunitas cyber yaitu, roleplay. Istilah roleplay sendiri berarti berperan atau memerankan (seseorang). Biasanya istilah ini dipakai untuk menggambarkan aktivitas yang dilakukan oleh pemain-pemain drama atau teater. Lambat laun, roleplay berkembang, tidak hanya digunakan sebagai istilah untuk pemain drama atau teater, namun juga menjadi istilah umum yang digunakan untuk menggambarkan aktivitas seseorang saat memerankan orang lain sebagai dirinya. Hal tersebut diadaptasi ke sebuah permainan yang dapat dimainkan siapa saja dengan berbagai media yang tersedia. Salah satunya roleplay yang saat ini sudah mewabah di media sosial twitter.

Para pelaku roleplay di twitter sendiri biasanya memerankan tokoh-tokoh idola yang berasal dari Barat, Jepang, dan Korea 
sedangkan pada penelitian ini peneliti akan memfokuskan pada pelaku roleplay yang memerankan tokoh idola yang berasal dari Korea karena sudah menjadi hal yang tidak lagi asing bagi masyarakat khususnya remaja untuk mengetahui tentang budaya Korea atau lebih dikenal Korean Wave sehingga menjadi yang paling mendominasi dalam dunia roleplay itu sendiri. Biasanya roleplayer yang memerankan tokoh yang berasal di Korea berkaitan erat dengan Korean Pop atau sering disebut dengan K-POP. Mereka lebih sering memerankan penyanyi - penyanyi terkenal yang berasal dari Korea dan kebanyakan para pelaku roleplay memerankan hal tersebut hanya sebagai sarana hiburan.

Pada umumnya roleplayer dituntut untuk memahami dan menyerupai karakter yang diperankannya mulai dari sifat, kesukaan, gaya bahasa yang digunakan hingga cara berpikir tokoh tersebut. Pada umumnya roleplayer dituntut untuk memahami karakter yang diperankannya mulai dari sifat, kesukaan, latar belakang, gaya bahasa yang digunakan hingga cara berpikir tokoh tersebut dan berinteraksi dengan sesama Roleplayer menggunakan alur atau plot yang diciptakan. Sedangkan, dalam melakukan roleplay di twitter ini terdapat berbagai jenis karakter yang akan diperankan, seperti OOC (out of character), Less OOC, dan IC (In Character).

1. $O O C$ sendiri merupakan kependekan dari Out Of Character yang berarti roleplayer keluar dari karakter tokoh yang diperankannya mulai dari sifat, sikap \& perilakunya.

2. Less OOC adalah tipe pemain roleplayer yang meminimalisir sifat $O O C$ mereka dan tetap mengikuti sifat dari tokoh yang diperankan.

3. IC (In Character) yang berarti pemain bertingkah laku layaknya karakter asli dari tokoh yang diperankannya, seperti menyesuaikan sifat dan kepribadiannya, yang pemain lakukan hanya berinteraksi secara normal menurut pandangan tokoh tersebut dan mengikuti schedule para tokoh yang diperankan.

Selain jenis dari karakter roleplay di twitter tersebut, terdapat pula akun roleplay agency yang menjadi tempat atau wadah bagi para roleplayer ditwitter bernaung.terdapat dua jenis agency yang ada pada dunia Roleplay, yaitu:

1. Open Agency dimana para roleplayer dapat melakukan interaksi dengan anggota diluar agency dan dapat memfollow akun roleplay diluar agency dan

2. Closed Agency yang dimana anggota tidak memiliki izin untuk berinteraksi atau saling mem-follow sesama akun roleplayer yang diluar keanggotaan agency yang diikutinya. Selain itu, Closed Agency tersebut juga tidak mengizinkan anggotanya untuk bergabung dengan agency lain. 
artis tidak berpasangan dengan orang tersebut. Dalam memilih couple tersebut terdapat berbagai cara, seperti akun base

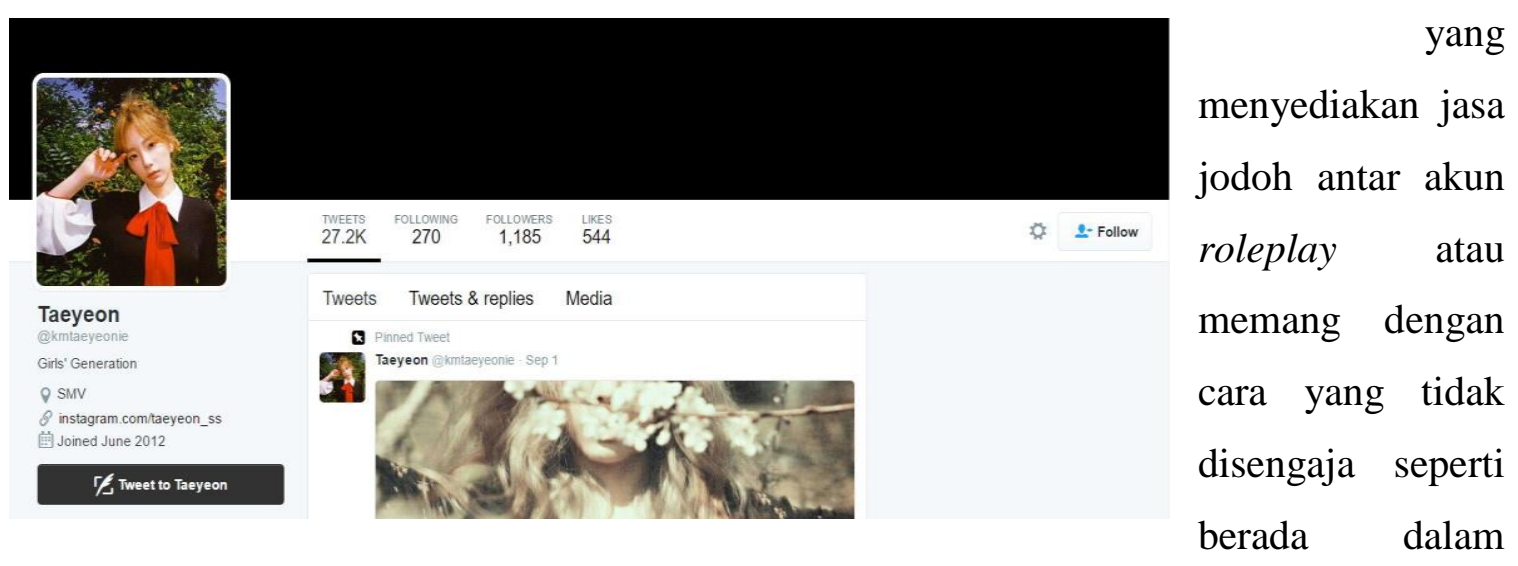

agensi yang sama.

Gambar I Salah Satu Akun Roleplay

di Twitter dengan username @kmtaeyeonie

Sumber: Dokumentasi Peneliti

(2016)

Dalam dunia Roleplay di twitter ini pun pemain bisa mendapatkan couple sesama pemain roleplay. Couple dalam roleplay tersebut bisa disesuaikan dengan

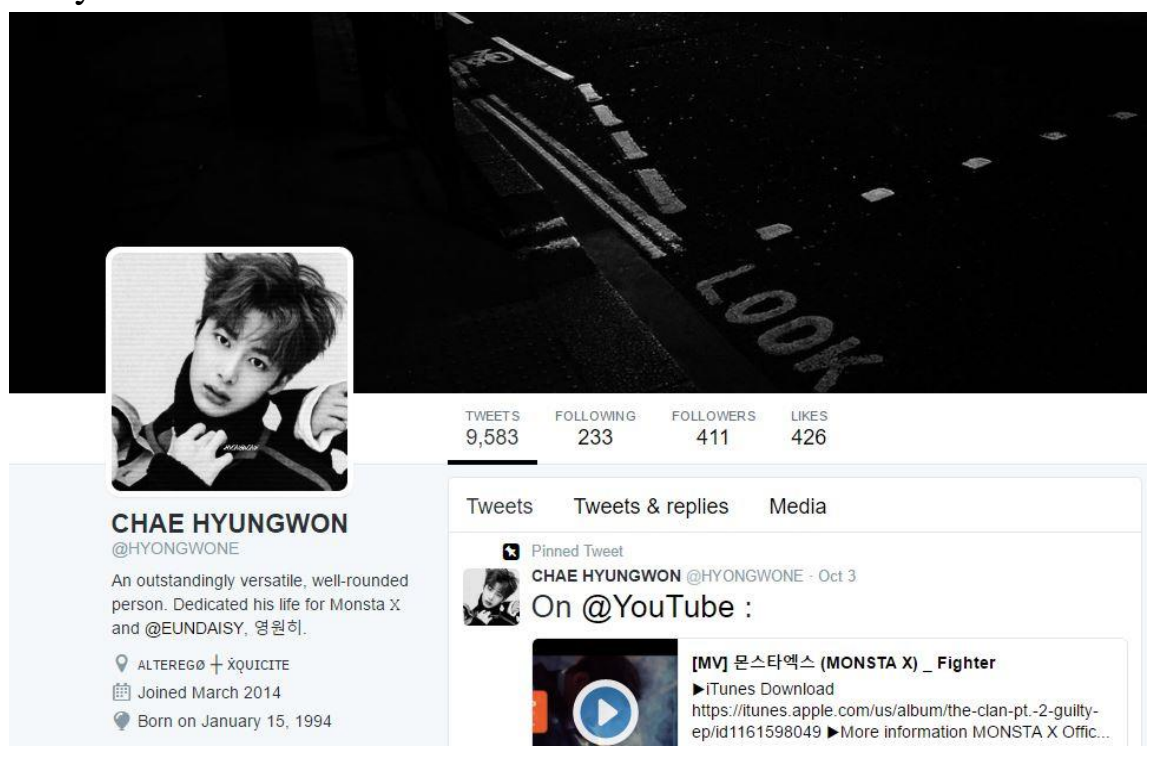
misalkan dalam dunia nyata Kai dari anggota boygroup EXO berpacaran dengan Krystal girlgroup $\mathrm{F}(\mathrm{x})$ kemudian pemain roleplay juga memilih pasangannya sesuai dengan kehidupan nyata sang artis yaitu akun roleplay Kai EXO berpasangan dengan akun roleplay Krystal $\mathrm{F}(\mathrm{x})$. Selain itu para roleplayer bisa bebas memilih couple yang ia sukai walaupun dalam kehidupan nyata sang

Gambar II Akun Pasangan Roleplayer Sumber: Dokumentasi Peneliti (2016)

Dunia roleplay seakan membuat realitas baru melalui dunia maya. Salah satu contohnya adalah adanya Penikahan Virtual bagi pasangan yang ada dalam dunia roleplay. Aktivitas dalam pernikahan virtual dalam dunia roleplay 
tersebut sama seperti pernikahan dunia nyata pada umumnya, seperti membuat undangan, menyusun rangkaian acara bahkan sampai adanya Wedding Organizer yang khusus bagi para pasangan roleplay yang ingin menikah.

Jalannya pernikahan virtual tersebut dilakukan dengan cara plotting yaitu berimajinasi untuk membuat suatu jalan cerita sesuai dengan keinginan sang roleplayer tersebut. Plotting itu sendiri bisa dilakukan oleh wedding organizer selaku penyusun acara maupun kedua mempelai roleplayer itu sendiri.

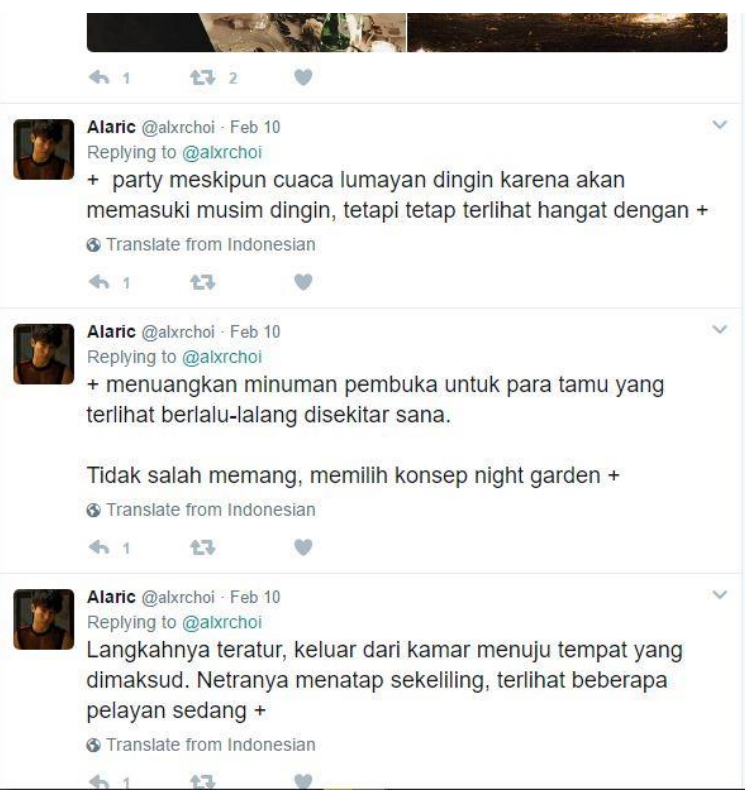

Gambar 4 Plotting yang dilakukan dalam Pernikahan Virtual Roleplay

Sumber: Dokumentasi Peneliti (2016)

Sebelum terjadinya realitas baru seperti adanya pernikahan virtual tersebut peneliti ingin mengetahui motif yang mendasari pasangan dalam dunia roleplay. Motif tersebut tentunya tidak lepas dari motif sosiogenesis atau motif sekunder seorang manusia karena peranannya sangat menentukan dalam membentuk perilaku manusia (Rakhmat, 2011:36). Maka dari itu, peneliti tertarik untuk melakukan penelitian mengenai Motif Sosiogenesis Pasangan Roleplay dalam Media Sosial Twitter dimana juga diikuti mengenai interaksi yang dilakukan pasangan roleplay tersebut.

Gambar 3 Undangan Pernikahan Virtual dalam Roleplay

Sumber: Dokumentasi Peneliti (2016)

\section{METODE PENELITIAN}

Dalam penelitian ini penulis menggunakan paradigma konstruktivisme. Paradigma konstruktvisme menyatakan bahwa individu melakukan interpretasi dan 
bertindak menurut berbagai konseptual yang ada didalam pikirannya. Konstruktivisme cenderung menggunakan pengalamannya sendiri yang dituangkan untuk menjadi suatu paradigma. Metode yang digunakan dalam penelitian ini adalah metode kualitatif. Bodgan dan Taylor, dalam Basrowi (2008) mendefinisikan metodologi kualitatif sebagai prosedur penelitian yang menghasilkan data deskriptif berupa kata-kata tertulis atau lisan dari orang-orang dan perilaku yang dapat diamati. Metode yang digunakan dalam penelitian ini adalah metode kualitatif. Bodgan dan Taylor, dalam Basrowi (2008) mendefinisikan metodologi kualitatif sebagai prosedur penelitian yang menghasilkan data deskriptif berupa kata-kata tertulis atau lisan dari orang-orang dan perilaku yang dapat diamati.

Teknik pengumpulan data yang dilakukan dalam penelitian ini adalah menggunakan teknik observasi dan wawancara mendalam terhadap informan. Teknik keabsahan data yang digunakan dalam penelitian ini adalah teknik triangulasi data yaitu triangulasi teknik. Triangulasi dalam pengujian kredibilitas ini diartikan sebagi pengecekan data dari berbagi sumber dengan berbagai cara, dan berbagai waktu. Dengan demikian terdapat triangulasi sumber, triangulasi teknik pengumpulan data dan waktu. (Sugiyono, 2014:125). Pendekatan yang dilakukan dalam penelitian ini adalah pendekatan etnografi virtual. Etnografi virtual merupakan metode etnografi yang dilakukan untuk melihat fenomena sosial dan/atau kultur pengguna di ruang siber. Bahkan Bell dalam Nasrullah (2014:171) menyatakan, bahwa metode etnografi merupakan metode utama dan penting untuk melihat fenomena budaya siber di internet. Dalam kajian etnografi virtual pola-pola pendekatan penelitian terhadap Internet bisa dilakukan tergantung dari bagaimana individu memandang Internet. Sebagai sebuah kultur dan artefak kultural, cyberspace atau dunia siber bagi peneliti etnografi virtual bisa mendekati beberapa objek atau fenomena yang ada di internet. Identitas, komunitas dan perkembangan teknologi Internet memang merupakan isu utama yang sering dibahas Nasrullah (2014:172). Selain itu, Hine dalam Nasrullah (2014:174) menegaskan bahwa selain melakukan penelitian secara online peneliti juga diharapkan dapat bertemu dengan subjek penelitiannya secara langsung dalam konteks ini bisa menggunakan media internet itu sendiri seperti e-mail, atau konferensi video melalui video call. Hal ini dilakukan untuk memverifikasi informasi yang diberikan dan memastikannya dengan kehidupan offline subjek dan untuk mendapatkan konfrimasi terhadap realitas di dalam cyberspace dari pengguna langsung sampai pada motif yang melandasi pengguna yang menyebabkan temuan penelitian itu. 


\section{HASIL DAN PEMBAHASAN}

Dalam bab ini, peneliti akan menjelaskan dan menguraikan serta menganalisis data dari hasil penelitian yang telah dilakukan mengenai fokus permasalahan dalam penelitian. Tujuannya untuk mengetahui dan memahami mengenai motif sosiogenesis pada pasangan roleplay dalam media sosial twitter.

Tabel I Profil Singkat Informan

a. Motif ingin tahu

Mengerti, menata, dan menduga (predictability). Kecenderungan untuk memberi arti pada apa yang dialami, bila informasi yang diperoleh terbatas, orang akan mencari jawaban sendiri; orang akan menarik kesimpulan tanpa menunggu sampai informasi itu lengkap lebih dahulu.

\begin{tabular}{|c|c|c|c|c|}
\hline No & $\begin{array}{c}\text { Nama } \\
\text { (disamarkan) }\end{array}$ & $\begin{array}{c}\text { Akun } \\
\text { Roleplayer }\end{array}$ & Pasangan & $\begin{array}{c}\text { Lama } \\
\text { menjadi } \\
\text { pasangan }\end{array}$ \\
\hline 1. & Rose & @parkjihyoe & @Def_soul_jbi & 20 bulan \\
\hline 2. & Dave & @Def_soul_jbi & @ parjihyoe & 20 bulan \\
\hline 3. & Jichu & @JICHO0 & @ sonxmmino & 3 bulan \\
\hline 4. & Emon & @ sonxmmino & @JICHO0 & 3 bulan \\
\hline
\end{tabular}

b. Motif kompetensi. Setiap orang ingin membuktikan bahwa ia mampu mengatasi persoalan kehidupan apa Sumber: Olahan Peneliti (2016)

pun. Perasaan mampu amat bergantung pada perkembangan intelektual, sosial, dan emosional.

Dalam penelitian ini peneliti menggunakan konsep motif dari Jalaluddin Rakhmat yaitu motif sosiogenesis. Motif sosiogensis, sering juga disebut motif sekunder. Artinya adalah seseorang yang tidak memenuhi kebutuhan ini, tetap dapat melangsungkan hidup, namun terjadi banyak perubahan perilaku. Motif sosiogenesis merupakan dorongan yang timbul akibat adanya kebutuhan-kebutuhan dalam hal sosial, interaksi dan pemenuhan diri. Berikut jenis-jenis dari motif sosiogenesis:
Motif kompetensi erat hubungannya dengan kebutuhan akan rasa aman

c. Motif cinta. Sanggup mencintai dan dicintai adalah hal esensial bagi pertumbuhan kepribadian. Orang ingin diterima di dalam kelompoknya sebagai anggota sukarela dan bukan yang sukar rela. Kehangantan persahabatan, ketulusan kasih sayang, penerimaan orang lain yang hangat amat dibutuhkan manusia. 
d. Motif harga diri dan kebutuhan mencari identitas. Erat kaitannya dengan kebutuhan untuk memperlihatkan kemampuan dan memeroleh kasih sayang, ialah kebutuhan untuk menunjukkan eksistensi di dunia.

e. Kebutuhan akan nilai, kedambaan, dan makna kehidupan. Manusia membutuhkan nilai-nilai untuk menuntutnya dalam mengambil keputusan atau memberikan makna pada kehidupannya. Termasuk ke dalam motif ini adalah motif-motif keagamaan.

f. Kebutuhan pemenuhan diri. Kita bukan saja mempertahankan kehidupan, kita juga ingin meningkatkan kualitas kehidupan kita; ingin memenuhi potensipotensi kita.

Sedangkan yang peneliti temukan dari konsep motif sosiogenesis terseut pada penelitian ini adalah motif ingin tahu, otif cinta dan motif harga diri.

Berdasarkan hasil wawancara yang telah peneliti lakukan kepada keempat informan, peneliti menemukan bahwa motif yang mendasari adanya pasangan roleplay dalam media sosial twitter adalah adanya rasa ingin tahu informan terhadap seseorang yang diperankan dan seseorang yang memerankan karakter di dalam dunia roleplay.
Rasa ingin tahu terhadap seseorang yang diperankan muncul karena berawal dari mengidolakan tokoh idola yang berasal dari Korea yang kemudian menemukan tokoh tersebut sebagai akun roleplay yang membuat tiga dari empat informan yaitu Dave, Emon dan Jichu muncul rasa ingin tahu lebih lanjut mengenai tokoh tersebut. Berdasarkan pernyataan Dave, Emon, Jichu bahwa pada awalnya mereka tertarik dengan pasangannya dalam dunia roleplay saat ini karena pasangan masing-masing memerankan tokoh yang Dave, Emon dan Jichu idolakan.

Dengan adanya ketertarikan pada seseorang yang diperankan tersebut, akhirnya membuat mereka ingin mengetahui lebih lanjut mengenai seseorang dibalik yang memerankan tokoh idolanya tersebut, setelah mengenal kepribadian dari seseorang yang memerankan tokoh idolanya tersebut, akhirnya membuat Dave, Emon dan Jichu merasa tertarik dengan pasangannya masingmasing dan munculah adanya perasaan nyaman, mendapatkan chemistry satu sama lain dan sifat pasangan yang baik membuat Dave, Emon dan Jichu semakin ingin mengetahui lebih dalam tentang pribadi sebenarnya dari seseorang yang memerankan tokoh tersebut.

Berbanding terbalik dengan tiga informan sebelumnya, Rose, menyukai pasanganya karena adanya rasa ingin tahu terhadap kepribadian/perilaku sebenarnya dari seseorang yang memerankan tokoh idola 
tersebut yang pada akhirnya membuat Rose tertarik dengan pasangannya yang membuat ia merasa nyaman dan selalu terhibur karena sifat lucu dari pasangannya tersebut.

Selain itu, menurut pengakuan informan, awal mula ia menemukan pasangannya tersebut di dunia roleplay adalah karena diperkenalkan oleh teman sesama roleplayer, yang kemudian rasa ingin tahu terhadap seseorang yang diperankan dan seseorang memerankan tokoh idola tersebut muncul dalm diri informan.

Seperti yang diungakapkan Rakhmat (2011: 37) motif ingin tahu merupakan salah satu dari motif seosiogenesis atau motif sekunder, motif ingin tahu tersebut berarti setiap orang berusaha memahami dan memeroleh arti dari dunianya.

Berdasarkan pembahasan diatas, dapat diasumsikan bahwa yang menjadi alasan informan dalam memiliki pasangan roleplay adalah karena seseorang yang diperankan dan seseorang yang memerankan roleplay tersebut.

Berdasarkan hasil wawancara yang telah dilakukan pada informan dalam penelitian ini, keempat informan memberikan alasan yang membuatnya memilih pasangannya dalam dunia roleplay adalah karena pribadi/perilaku sebenarnya yang ditunjukkan pada pasangan masing-masing.

Motif Cinta sendiri merupakan salah satu dari motif sosiogenesis atau lebih dikenal dengan motif sekunder, Rakhmat (2011) mengatakan bahwa, sanggup mencintai dan dicintai adalah hal esensial bagi pertumbuhan kepribadian. Orang ingin diterima di dalam kelompoknya sebagai anggota sukarela dan bukan yang sukar rela. Kehangatan persahabatan, ketulusan kasih sayang, penerimaan orang lain yang hangat amat dibutuhkan manusia.

Dengan munculnya pribadi/perilaku sebenarnya tersebut, kemudian muncul jugalah perasaan dicintai dan mencintai dari diri para informan. Pribadi/perilaku sebenarnya muncul dalam diri informan karena sudah adanya faktor kenyamanan dan chemistry seperti yang telah diungkapkan pada sub bab sebelumnya. Akibat adanya faktor merasa nyaman dan chemistry dengan pasangannya tersebut, akhirnya membuat masing-masing informan menemukan perasaan ingin menunjukkan kepribadian/perilaku sebenarnya kepada pasangannya masing-masing.

Dengan menunjukkan pribadi/perilaku sebenarnya tersebut, informan merasakan adanya timbal balik positif yang diberikan oleh masing-masing pasangan sehingga membuat diri informan juga merasa dicintai. Adapun beberapa contoh pribadi/perilaku sebenarnya yang ditunjukkan pada masingmasing pasangan roleplay tersebut ialah seperti memberikan perhatian, humoris, kedewasaan menghadapi pasangan roleplay, clingy (tidak bisa jauh), sifat yang baik, selalu 
memberikan dukungan sehingga membuat para informan merasa dicintai dan mencintai.

Hal ini sesuai dengan observasi yang telah peneliti lakukan pada akun roleplay masing-masing informan saat melakukan mention, peneliti menemukan bahwa adanya perlakuan positif yang dilakukan oleh informan terhadap pasangannya tersebut seperti memberikan kata-kata manis juga memberikan dukungan satu sama lain.

Berdasarkan pembahasan diatas, dapat diasumsikan bahwa informan merasakan dicintai dan mencintai terhadap pribadi/pelaku sebenarnya yang ditunjukkan oleh pasangan masing-masing yang berawal dari adanya rasa nyaman dan adanya chemistry dari masing-masing pasangan.

Motif harga diri merupakan salah satu bagian dari motif sosiogenesis, atau lebih dikenal dengan motif sekunder. Menurut Rakhmat (2011), motif ini erat kaitannya dengan kebutuhan untuk memperlihatkan kemampuan dan memeroleh kasih sayang, ialah kebutuhan untuk menunjukkan eksistensi di dunia.

Berdasarkan hasil wawancara yang telah peneliti lakukan kepada keempat informan, peneliti menemukan adanya motif harga diri pada diri informan mengenai adanya pasangan roleplay ini. Motif harga diri ini muncul karena adanya keingin tahuan informan terhadap respon yang didapat dari masing-masing pasangannya atas pribadi/perilaku yang telah ditunjukkan oleh informan.

Tiga dari empat informan yang ada dalam penelitian ini, mengaku bahwa ia merasa dihargai oleh pasangannya, hal ini di buktikan dengan pernyataan informan yang menceritakan bagaimana pasangannya memperlakukan informan dengan hal yang positif seperti merasa diprioritaskan, menujukkan perasaan cintanya, adanya kejujuran satu sama lain.

Adapun satu dari empat informan merasa bahwa ia tidak dihargai oleh pasangannya karena respon yang ditunjukkan kepada informan adalah negatif seperti menjadi posesif sehingga membuat informan merasa risih dan merasa tidak sebanding dengan apa yang ia lakukan pada pasangannya tersebut.

Berdasarkan pembahasan diatas, dapat diasumsikan bahwa informan merasa dihargai oleh pasangannya karena adanya respon positif yang ditunjukkan oleh pasangannya terhadap informan dan munculnya perasaan yang semakin besar terhadap pasangan dari masing-masing informan.

Dalam penelitian ini, peneliti menemukan media lain yang digunakan dalam berkomunikasi oleh informan dengan pasangan roleplaynya. Selain melalui fiturfitur yang disediakan oleh twitter itu sendiri, para informan memiliki pilihannya sendiri dalam memilih media yang digunakan untuk 
menunjang mereka dalam berkomunikasi dengan pasangannya secara pribadi.

Hal tersebut sesuai dengan John December (dalam Widjajanto 2013:143) mengatakan bahwa CMC merupakan proses komunikasi manusia dengan menggunakan komputer yang melibatkan sejumlah orang dalam situasi dengan beragam konteks, yang terjadi dalam proses untuk media dengan berbagai tujuan. Selain itu, menurut Walter (dalam Widjajanto 2013:145) CMC diyakini lebih bersahabat dibandingkan dengan komunikasi konvensional karena diyakini lebih bersahabat, sosial dan akrab karena pada dasarnya manusia selalu didorong hasrat berkomunikasi denga melampaui rintangan teknologi dan bahkan memnafaatkan teknologi untuk memaksimalkan kepuasa berkomunikasi dan berinteraksi. Setidaknya ada tiga alasa utama mengapa seseorang bisa lebih menikmati CMC dibandingkan dengan komunikasi yang konvensional, yaitu:

1) Pengguna media computer seringkali berbagi atau menyebarkan keanggotaan grup dengan pemikiran bahwa mereka dan anggota grup lainnya memiliki kesamaan

2) Tipikal anonym pada CMC dapat membuat seseorang semakin mengekspresikan diri dan mungkin tidak perlu khawatir atas penampilan mereka
3) CMC member kesempatan penggunanya lebih dalam berpikir dan mungkin tidak terlalu terganggu dengan situasi yang tengah terjadi. Komunikasi jenis ini juga membuat seseorang merasa nyaman dan senang jika ada orang lain yang memberi perhatian padanya.

Fitur - fitur yang disediakan oleh twitter sendiri yang biasa digunakan oleh informan dan pasangannya adalah seperti melalui mention dan direct message. Namun, bagi pasangan Rose dan Dave lebih memilih aplikasi messenger kakaotalk dibanding media lainnya. menurut pernyataan keduanya, alasan mereka menggunakan media kakaotalk sebagai penunjang interaksi karena media kakaotalk tersebut merupakan media dimana para roleplayer berkomunikasi, sehingga dapat diasumsikan bahwa media kakaotalk merupakan media interaksi bagi semua roleplayer bukan hanya untuk couple saja. Selain itu, alasan mereka memilih aplikasi kakaotalk sebagai media penunjang interaksi karena merasa lebih nyaman dan lebih terjaga privasinya.

Berbeda dengan pasangan Jichu dan Emon yang memilih direct message Instagram dan aplikasi messenger Line sebagai media penunjang interaksi yang dilakukan oleh mereka selain fitur-fitur yang disediakan oleh twitter dan biasa digunakan oleh mereka yaitu mention dan direct 
message. Pada hasil wawancara dengan Jichu dan Emon, mereka mengungkapkan bahwa setelah menjalin hubungan sebagai pasangan roleplay, mereka memutuskan untuk bertukar akun instagram asli masing-masing. Sehingga dapat diasumsikan bahwa tak jarang mereka melakukan interaksi melalui direct message instagram. Selain itu, mereka memiliki media lainnya yang juga sebagai penunjang dalam berinteraksi yaitu aplikasi Line Messenger, dan tentunya itu adalah akun asli dari pemeran Jichu dan Emon di dunia roleplay. Alasan yang digunakan oleh Jichu adalah karena adanya rasa takut akan kehilangan Emon dalam dunia roleplay, dalam arti Jichu takut jika Emon sudah tidak bermain roleplay sehingga membuatnya memilih aplikasi line messenger sebagai media berinteraksi, berbeda dengan Emon yang hanya menganggap bahwa itu hanya sekedar untuk mendapat teman baru yang dikenalnya dari dunia maya.

Dapat ditarik kesimpulan, bahwa media yang digunakan pasangan roleplay adalah mention dan direct message di twitter, KakaoTalk dan juga Line messenger.

Berdasarkan hasil wawancara kepada keempat informan, peneliti menemukan hal mengenai dampak dari intensitas interaksi yang dilakukan oleh informan dengan pasangannya masing-masing, dari intenitas interaksi tersebut berdampak pada hubungan mereka sebagai pasangan di dunia roleplay dan juga pada pribadi mereka sendiri.
Pada hasil wawancara juga disebutkan bahwa keempat informan melakukan interaksi yang cukup intens dengan pasangannya, hal ini ternyata menpengaruhi ke dalam hubungan mereka sebagai pasangan dalam dunia roleplay. Menurut pengakuan Rose dan Dave, karena dalam berinteraksi mereka terbilang cukup intens, sehingga muncul lah perasaan merasa lebih dekat dengan pasangan, mulai terbuka dengan kehidupan asli dari masing-masing, lebih memahami pasangan dengan kehidupan aslinya.

Selain itu, pengaruh intensitas interaksi tersebut juga mempengaruhi ke dalam pribadi masing-masing antara Rose dan Dave, Rose mengatakan bahwa ia menjadi segan ketika ada pria lain dalam kehidupan nyata mulai mendekatinya karena ia merasa sudah memiliki pacar, yang pada kenyataannya ia memiliki pacar hanya dalam dunia roleplay saja. Sama seperti Rose, Dave juga merasa intensitas tersebut mempengaruhinya ke dalam kehidupan aslinya seperti menjadi sering memikirkan Rose ketika mereka dalam keadaan bertengkar, dan membuat suasana hatinya tidak enak ketika melakukan kegiatan dalam kehidupan aslinya.

Jichu dan Emon sendiri merasa bahwa dalam intensitas interaksi yang dilakukan mempengaruhi ke dalam hubungan mereka, dampak yang dirasakan mereka cenderung lebih ke hal yang negatif, karena ada pikiran negatif yang terlintas ketika Emon lama 
dalam membalas pesan Jichu, dan memicu adanya pertengkaran dan munculnya sifat posesif dalam diri Jichu.

Selain mempengaruhi kedalam hubungan, Jichu dan Emon juga merasakan adanya pengaruh ke dalam pribadi mereka masing-masing. Jichu merasa menjadi lebih sering untuk memegang handphone hanya karena untuk melakukan hal kecil untuk Emon. Sedangkan menurut Emon pengaruh yang dirasakan dalam dirinya adalah dalam dunia roleplay ini ia jadikan sebagai media yang digunakannya dalam menguji dirinya sendiri untuk memahami dan menghadapi wanita.

Melalui identitas online, dimana seseorang bisa membentuk sebuah identitas yang diinginkan yang kemudian muncul sebuah identitas baru yang lebih menarik dan juga terbentuknya sebuah hubungan baru khususnya persahabatan atau bahkan asmara. Dari internet sendiri menawarkan kesempatana baru unruk menciptakan sebuah hubungan. Dalam CMC seseorang cenderung lebih memiliki kesamaan minat, nilai dan berfokus pada gaya percakapan satu sama lain dibanding memperhatikan penampilan (McKenna dan Bargh dalam Nancy, 2006). Dalam waktu ke waktu, CMC lebih mirip dengan komunikasi tatap muka dalam hal percakapan sosioemosional dan pembentukan kesan oleh seseorang dibaliknya. Hubungan yang kuat muncul secara online karena adanya keininginan dari seseorang untuk melakukan komunikasi secara intens dan mendapatkan timbal balik yang dinginkan (Wellman dan Gulla dalam Nancy, 2006) dan dengan keberadaan internet itu sendiri dapat membantu orang-orang untuk saling menjaga hubungan satu sama lain dengan cara yang lebih modern.

Selain itu, Devito dalam Laksana (2015:67) mendefinisikan komunikasi interpersonal sebagai proses pengiriman dan penerimaan pesan-pesan antara dua orang atau sekelompok kecil orang-orang dengan beberapa efek dan beberapa umpan balik seketika.

Berdasarkan pembahasan diatas serta teori yang ada, dapat diasumsikan bahwa intensitas interaksi yang dilakukan oleh pasangan roleplay menimbulkan beberapa efek negatif yang dapat mempengaruhi ke dalam hubungan mereka yang hanya sebagai pasangan roleplay dan juga mempengaruhi pribadi mereka sendiri sebagai seseorang yang memerankan tokoh idola.

\section{SIMPULAN}

Berdasarkan hasil penelitian yang telah dijabarkan dan dianalisa, makan peneliti dapat menarik kesimpulan mengenai motif sosiogensis pasangan roleplay pada media sosial twitter adalah sebagai berikut:

1. Menurut hasil penelitian dan analisa, peneliti menemukan tiga motif yang mendasari informan yang akhirnya menjadi pasangan dalam dunia roleplay 
pada media sosial twitter. Motif yang pertama adalah motif ingin tahu, yang berarti motif ini muncul karena adanya rasa ingin tahu pada karakter/tokoh yang diperankan roleplayer dan seseorang yang memerankan karakter/tokoh yang diperankan. Motif yang kedua adalah motif cinta yang berarti adanya rasa untuk mencintai dan dicintai pada seseorang yang memerankan karakter/tokoh dengan menunjukkan sifat dan perilaku sebenarnya. Motif yang terakhir adalah motif harga diri yang berarti adanya perasaan untuk merasa dihargai oleh pasangan. Sehingga peneliti juga menemukan dalam penelitian ini bahwa mereka memang memerankan karekater/tokoh idola, namun tetap menggunakan perasaan aslinya sehingga berpengaruh kedalam kehidupan asli pemain roleplay tersebut.

2. Menurut hasil penelitian, peneliti menemukan bahwa dalam berinteraksi dengan pasangan dalam dunia roleplay ada beberapa media yang digunakan oleh informan dalam melakukan interaksi, yaitu melalui aplikasi messenger kakaotalk dan juga melalui aplikasi Line Messenger. Selain itu, peneliti juga menemukan bahwa dalam berinteraksi, yang informan ini dilakukan cukup intens dan intensitas interaksi yang dilakukan oleh informan dapat mempengaruhi ke dalam hubungan mereka, pengaruh yang dirasakan terbagi menjadi dua yaitu ke dalam hal positif dan juga negatif. Positif, karena mereka merasa lebih dekat dan lebih mengetahui juga memahami sifat asli yang ditunjukkan oleh pasangannya. Negatif, karena merasa sudah memiliki sepenuhnya sehingga timbul perasaan takut kehilangan yang berujung pada bertengkar dan membawa suasana yang buruk ke dalam kehidupan nyata. Selain mempengaruhi kedalam hubungan, intensitas interaksi tersebut juga mempengaruhi kedalam diri informan yaitu seperti sudah menganggap bahwa pasangan mereka dalam dunia roleplay merupakan pasangan asli informan dalam kehidupan nyata.

\section{DAFTAR PUSTAKA}

Basrowi \& Suwandi. (2008). Memahami Penelitian Kualitatif. Jakarta: Rineka Cipta

Berger, Charles,dkk. 2014. Handbook Ilmu Komunikasi. Bandung: Nusamedia

Laksana, Muhibudin Wijaya. (2015). Psikologi Komunikasi (Membangun Komunikasi yang Efektif dalam Interaksi Manusia). Bandung: CV Pustaka Setia

Mahameruaji, dkk. (2016). Perbincangan Mengenai Hukuman Mati Terpidana Kasus Bali Nine dan Mary Jane dalam situs Jejaring Sosial Twitter. Diambil dari http://jurnal.unpad.ac.id/jkk/article/v iew/7817/4285 (tanggal 10 Juni 2017)

Nasrullah, Rulli. (2014). Teori dan Riset Media Siber 
(Cybermedia). Jakarta:

Kencana

Nasrullah, Rulli. (2015). Media Sosial.

Bandung: PT Remaja Rosdakarya.

Rakhmat, Jalaludin. (2011). Psikologi

komunikasi. Bandung : PT Remaja

Rosdakarya

Ronauli, M., Wahyudin, U., Elita, F.U.,

Mirawati, I., 2016, HUBUNGAN

ANTARA PESAN KAMPANYE 9

AKSI RAMAH LINGKUNGAN DI

AKUN TWITTER EARTH HOUR

BANDUNG DENGAN SIKAP

FOLLOWERS AKTIF TERHADAP

GAYA HIDUP RAMAH

LINGKUNGAN, diakses dari

http://jurnal.unpad.ac.id/manajemen-

komunikasi/article/view/11017/4924

Sugiyono.( 2014). Memahami Penelitian

Kualitatif. Bandung: Alfabeta

Suryano. (2015). Pengantar Ilmu

Komunikasi. Bandung: CV Pustaka

Setia

Wiryanto, (2000). Teori Komunikasi Massa. Jakarta: Grasindo

Widjajanto, Kenmada. (2013).

Perencanaan Komunikasi:

Konsep dan Aplikasi. Bandung:

Ultimus 